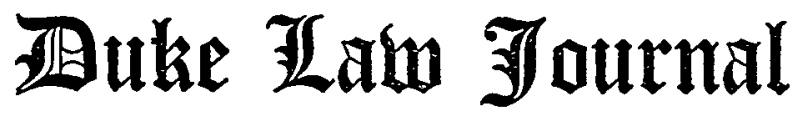

\begin{tabular}{lll}
\hline Volume I96I & AUTUMN & NUMBER 4 \\
\hline
\end{tabular}

\section{UNION SECURITY AND THE TAFT-HARTLEY ACT}

\author{
ERWIN S. MAYER*
}

$I^{\mathrm{N}}$

$\mathrm{N}$ analyzing the law of labor relations, it is useful to regard it as governing a tripartite, private relation between employers, employees, and unions. The federal labor legislation of the two decades prior to 1947 consisted largely of a set of restraints placed on employers in their relations especially with unions. One may view the union-security provisions of the Taft-Hartley Act ${ }^{1}$ as an attempt to place parallel restraints on unions in their relations with employers and with employees. But whereas in the former case the law essentially regarded the union as an aggregate or extension of its members, in the latter case, the law may be said to have taken cognizance of the fact that the union exists as a separate entity with interests that may not always be consistent with those of actual or potential members.

While it is clear that the Taft-Hartley Act has placed a number of other restrictions upon unions, this particular restraint appears to have been of greatest moment to them, if one may judge from the volume of comment they have lavished on the union-security provisions of the law in their official publications. It is the purpose of this article to assemble and to evaluate the objections unions have raised against the union-security provisions of the Taft-Hartley Act. ${ }^{2}$

* A.B. I949, Hunter College; Ph.D. 1956, University of Washington; Chairman, Department of Economics, Business and Government, Western Washington College.

${ }^{1} 6$ I Stat. 136 (I947), 29 U.S.C. $\$ \S$ I4I-97 (1958).

${ }^{2} \mathrm{~A}$ word is in order about the sources of this article. In a broader survey of union attitudes toward the Taft-Hartley Act, the results of which are contained in Mayer, Union Attitudes Toward the Taft-Hartley Act: $x 947^{-x} 954$ (unpublished Ph.D. dissertation, University of Washington, 1956), the writer surveyed some 1,476 articles which appeared in twenty-one union periodicals between 1947 and 1954. All of these articles dealt, in one way or another, with the Act. Some idea may be gleaned of the relative importance attached by unions to the changes in union-security arrangements from the fact that more than one-fourth of all of the articles dealt with this particular issue. 
It seems desirable to preface the main body of this article with a brief discussion of the present legal status of union security under federal law. With the exception of the Railway Labor Act of $1926,{ }^{3}$ federal legislation had imposed no restrictions on union-security agreements, provided the union involved was a bona fide labor organization not dominated by an employer. This writer would deny the validity of the contention to the contrary-viz., that the proviso to section $8(3)$ of the Wagner $\mathrm{Act}^{4}$ merely represented congressional acquiescence to state law on the matter. ${ }^{5}$ However one may read section $8(a)(3)$ and its proviso, it exempted the closed shop and similar arrangements from the more general ban on discrimination in employment, which clearly had been intended to deal with employer discrimination against union members. In the Taft-Hartley Act, the proviso is changed so as to prohibit any discrimination in hiring based on union membership, but it permits the conclusion of union-shop agreements. Until 195I, when the Act was amended, the negotiation of such an agreement had to be preceded by an authorization election in which a majority of the employees concerned had voted to authorize negotiation of a union shop. Further, in order to be eligible to petition for such an election, compliance with the various filing requirements of the Act had been incumbent upon the petitioning union. The I95 I amendment removed the election requirement but made possible the rescission of a union's authority to enter into a union-shop agreement by means of a so-called deauthorization election. $^{6}$

The Taft-Hartley Act provides that an employer may not enforce a union-shop clause against a nonunion worker if the employer has reason to believe that the employee was refused membership on normal terms or that he was expelled from the union for any reason other than his failure to tender the regular dues and initiation fees. Similarly, it is an unfair labor practice for a union to seek to enforce an unlawful unionsecurity agreement or to seek to enforce a lawful agreement in an unlawful manner. Further, section $8(\mathrm{~b})(5)$ makes it an unfair labor practice for a union to impose excessive or discriminatory initiation fees under a union-shop agreement. Finally, section 14(b), currently the most controversial section of the Act, confers upon state law supremacy

\footnotetext{
${ }^{3} 44$ Stat. 577 (1926), 45 U.S.C. \$§ 151-88 (1958).

49 Stat. 452 (1935), as amended, 29 U.S.C. $\$ 158$ (1958).

'Reilly, State Rights and the Law of Labor Relations, in Chamberlin, ET AL., Labor Unions and Public Policy 107 (1958).

${ }^{8} 65$ Stat. 601 (1951), 29 U.S.C. \& 159 (e) (1958), amending 61 Stat. 143 (1947).
} 
over federal law with respect to union security, provided the former is more restrictive than the latter.

The subject matter of this article may conveniently be divided into the following categories: (I) the closed shop; (2) limitations on the union shop; (3) prerequisites to the negotiation and enforcement of the union shop; and (4) the union hiring hall. Clearly, under the TaftHartley Act the hiring hall is a special case of the closed shop; but for reasons that will become apparent, it will be discussed separately.

\section{The Closed Shop}

Though there are a number of general objections to the ban on the closed shop, alleging that it represents bad legislative judgment, most of the articles on the closed shop present specific grievances. The International Typographical Union was among the first to be affected by this aspect of the new law, because of its long-term commitment to the closed shop and because of the fortuitous circumstance that a number of its contracts expired shortly after the Taft-Hartley Act went into effect. The initial position adopted by the ITU admitted of no compromise. Woodruff Randolph, then ITU president, took the position that the union would not give up the closed shop; that if it could not contract for it, it would enter into no contract, but would insist on the observance of all ITU laws (including those pertaining to the closed shop); and that ITU members would not work in any shop that did not adhere to ITU laws. ${ }^{7}$ The union further charged that the intent of the American Newspaper Publishers Association in filing complaints against the ITU was to "inject competing non-union men" into the jobs of union men. ${ }^{8}$ When the union, after much litigation, was finally convicted of a charge of refusal to bargain, it was forced to abandon its policy. It persisted, however, in refusing to discipline members unwilling to work with nonunion men. ${ }^{9}$

It is argued repeatedly that the ban on the closed shop represents an unwarranted interference with the right of the parties to a contract to agree on terms suitable to themselves. An exaggerated form of this thesis is found in a speech by the president of the Wisconsin Federation.

\footnotetext{
${ }^{3}$ The Federal and State Laws Against Closed Shop, II Typographical J. 12 (1947).

The NLRB Case Against the ITU in Baltimore, Md., II TYPographical J. 362 (1947).

- Involuntary Servitude, 12 TYPographical J. 10 (I948).
} 
of Labor, in which he stated that "... the government says it is a criminal offence to enter into an agreement, subject to a rather stiff fine and incarceration in a federal penal institution. . .."10 Presumably this refers to a contempt action that might arise out of a refusal to enter into a lawful agreement rather than, as the quoted phrase suggests, a criminal action arising out of an unlawful contract. Since no other form of criminal action can arise under title one of the act, this appears to be the only possible interpretation.

One of the few arguments against the ban on the closed shop with which many students of the subject may agree is that it has tended to disturb cordial relations of long standing between employers and unions. Also found repeatedly is an argument exhuming once more the presumably long-laid ghost of the open shop, with its connotations of the American Plan of the I920's. Thus, in commenting on an unidentified. court decision dealing with union activity designed to encourage union members to refuse to work with nonmembers, George Meany argues that "the Taft-Hartley Law does what employers under the American Plan could not do."11 Nonetheless, it is doubtful that Mr. Meany would be willing to exchange the position of unions in $195 \mathrm{I}$ for their position in the I920's.

An interesting argument, not so much against the Taft-Hartley Act as in favor of the closed shop, is found in an editorial by the late William Green, who saw the closed shop as an institution of spiritual value to union men, in that it protects their right to work with whom they choose. ${ }^{12}$ A similar thesis was advanced by John L. Lewis in a press interview in which he denied the formal existence of the closed shop in the coal mines, but allowed that the spontaneous action of the miners might in effect result in a closed-shop situation, for ${ }^{13}$

that, after all, comes from the attitude of the men who go down into the mines as whether they would work there in the mine amid the hazardous conditions with a man they might call a hater of unions. ...

One Teamster spokesman combines this philosophical approach with a very practical one in an argument that has since been used as the basis for a new institution-i.e., the fee system. The writer argues that since the working conditions existing today represent an improvement at-

\footnotetext{
${ }^{10} 112$ Typographical J. 56 (1948).

${ }^{11}$ Our Job for 1952, Am. Federationist, Aug. 1951, p. 4.

10 Am. Federationist, Sept. 1948, p. 14.

${ }^{18}$ Lewis on "Meet the Press", U.M.W.J., May 15, 1954, p. 14.
} 
tained at a cost to union members, new employees have a moral duty to join the union if they want to partake of its benefits, and that the closed shop is the best way to provide assurance that the worker will see his moral duty properly. ${ }^{14}$

An interesting comment is found in the American Flint, to the effect that the ban on the closed shop has resulted, among other things, in widespread evasion of the law. ${ }^{15}$ It is widely known that this has, in fact, been true, though the extent of the evasion is obviously impossible to ascertain. One may suppose that evasion has been widespread in the building trades-a traditional closed-shop area-from the fact that no comment on this issue was found in the official journals of those buildingtrades unions covered in this survey. The vacillations in NLRB policy on jurisdiction over the building trades tend to reinforce this supposition.

Any kind of union-security agreement can be negotiated and enforced, so long as no one complains of the matter. It is quite conceivable that in some areas, where the supply of particular kinds of labor has traditionally been controlled by a union, where the union has not been unduly exclusive, and particularly where employers have been wont to use the union hall as an employment agency, the closed shop may be enforced for considerable periods of time, regardless of the law. It is only when an employer resists the demands of the union, or where an individual employee is refused employment because he lacks union membership and is sufficiently aware of his legal rights to complain to the NLRB, that the situation comes to official notice. Since there are no criminal provisions in the federal law, the risks to the union are quite small, though the monetary risks have been increased substantially by recent decisions.

In evaluating union comment on the union-security issue, and on the closed shop in particular, it is interesting to consider why most American unions attach so much importance to the matter. As the generic term suggests, such arrangements are intended to provide for the security of the union in its relations with the employer and with its members, to the extent that this end can be achieved by assuring that all employees of an employer are union members. Once the latter is assured, the union is thenceforth freed from the necessity of continuous organizational activity in that plant or shop. Obviously, the concern with union

${ }^{14}$ Taft Reverses Wagner Philosophy, International Teamster, March 1948, p. 20.

${ }^{16}$ The Mad Hatter, American Flint, May x950, p. 20. 
security must also be read in the light of a long history of employer tactics in resisting unionism. Under a closed or union shop, it becomes considerably easier for the union to display responsibility both in the enforcement of its contractual obligation to the employer and in the negotiation of new contracts. On the other hand, a secure union is in a better position to bargain from strength, without the histrionics some unions appear to believe essential for assuring the loyalty of the membership. Thus, to the employer, the advantages of dealing with a secure union are counterbalanced by the disadvantages of facing a strong union across the bargaining table. Presumably, an employer's attitude toward union security will be strongly colored by his evaluation of the relative advantages.

The arguments on the closed shop appear to bear out the above general speculations on union security. The closed shop is the unionsecurity device par excellence, since it assures the union that all employees are always members of the union and presumably in general agreement with its aims, since the union controls its own admission policies. Once achieved, the closed shop virtually obviates further organizing activity, since, in a sense, the employer, rather than the employee, has been organized. It is quite clear that this system can and has led to abuses. The degree of control over the supply of particular kinds of labor that is effected by the closed shop, when placed in the hands of a union that is disposed to restrict entry severely, is clearly against the public interest. Employees may easily be deprived of their right to choose their representatives after a closed shop has been in existence for some time, because of stringent union penalties against dual unionism. Should the union cease to serve the interests of its members, the closed shop can easily insulate the union against worker dissatisfaction. A further abuse of the closed shop, certainly not unknown, is the device of organizing workers indirectly, by entering into a closed-shop contract with a willing employer in the first instance, thus precluding workers from making a free choice at the outset. While one may agree that the closed shop is a means to industrial peace in many situations, it does not follow that its application in a manner inconsistent with the free choice of workers is justifiable. Certainly such an application conflicts not only with the Taft-Hartley Act, but with the spirit of the Wagner Act as well, which is to give workers wide latitude in their choice of bargaining agents. This, indeed, must be regarded as the essence of both laws.

The specific arguments that the ban on the closed shop interferes 
with the right to contract freely and that it upsets existing relationships of long standing cannot be taken too seriously. While the Act clearly does both, it is a well-established principle of law that private contracts violative of public policy do not enjoy the protection of law. Unions have long approved this principle in different contexts-e.g., the yellowdog contract, child labor, and so forth.

It is of interest, in analyzing union arguments concerned with the closed shop, to note that of 106 articles dealing with this topic, 85 appeared in AFL-union journals, and only 2I in the journals of CIO and independent unions. This compares to 178 and 196 articles, respectively, out of the total of 374 articles on all phases of union security covered by this study. While broad generalizations about craft and industrial unions, made on the basis of premerger affliation, are frequently unsound, in this instance, the generalization that craft unions have tended to show far more concern with this issue than have industrial unions seems useful, considering that it has been largely in craft-union areas of jurisdiction that the closed shop has been prevalent. It is not this writer's intention to imply some kind of mystical relation between craft consciousness and the closed shop. Rather, the point is that the closed shop has been an important protective device in those industrial areas where the unit of employment is typically small, where interemployer mobility is high, and where interoccupational mobility is low.

\section{II}

Limitations on the Union Shop and its Enforcement

A good deal of discussion is devoted to the limitations on enforcement of union-shop agreements. It is argued, for example, that this limitation tends to have the effect of making mere dues-payers of union members, since no participation in union affairs can be required by means of fines for non-attendance at union meetings and so forth. It is argued that this limitation is in direct conflict with one of the avowed objectives of the proponents of the law, the promotion of union democracy. ${ }^{16}$ It may be remarked that while attendance at meetings cannot be enforced by means of fines unless the member pays them voluntarily, ${ }^{17}$ the union can achieve the same objective by remitting part of the regular dues to those attending meetings, according to an obiter dictum contained in the decision cited.

\footnotetext{
${ }^{16}$ Taft Reverses Wagner Philosophy, International Teamster, March I948, p. 20.

${ }^{17}$ Electric Auto-Lite Company, 92 NLRB 1073 (i951).
} 
It is further alleged that the limitations on enforcement of the union shop leave the union vulnerable to penetration by various undesirables, such as thieves, spies, employer stooges, rats, scabs, sex perverts, dope adicts, and, in particular, Communists. The United Mine Workers Union argues, for example, that the Act is designed to create disrespect for the law, because of ${ }^{18}$

... the paradoxical provisions of the law which demand an anti-"Commie" affidavit from the officials of trade unions ... and at the same time compels trade unions to accept into membership an avowed member of the "Commie" party.

The obvious overstatement involved in this argument-i.e., that the law requires the union to accept various undesirables, is found with particular frequency in the Typographical Journal, which carried at least eight articles in this vein between 1948 and 1952 .

Found with greater frequency is the more realistic argument that the union can reject undesirables, but cannot force employers to discharge them, or prevent employers from hiring them, as the case may be. This argument has been found most often in the National Maritime Union's Pilot since the hiring hall was found to be unlawful. The point is made with considerable force by Joseph Curran, as follows: ${ }^{10}$

In seeking to invoke the Taft-Hartley Act, the shipping people are supporting the law that allows the dope fiends to ship while screening off the ships union members who stand for a principle. (Not only does the TaftHartley Law allow the dope fiend to ship, but the law protects the sex maniacs, the 'con' man, the dope peddlers, all the corrupt elements who make use of the 'Taft-Hartley Law to protect their 'rights' to ship outside the controls of a conscientious union.) Remember that the ship owners want to strengthen the law that protects our most dangerous elements.

The foregoing arguments provide an interesting glimpse at the contrast between the closed shop and the pre-Taft-Hartley union shop on the one hand, and the union shop permissible under the Act on the other, at least in the thinking of unions. Prior to the Taft-Hartley Act, the effective difference between the two arrangements were relatively minor. In many ways, both types of agreements achieved the same objectives, the sole difference being that under the union shop, control over hiring remained with the employer. It is not to be implied that

\footnotetext{
${ }^{18}$ There is Plenty for Labor to Think About, U.M.W.J., Sept. 1, 1947, p. 8.

${ }^{19}$ Passing the Word, Pilot, June 14, I 951 , p. 2.
} 
control over hiring, where it exists or existed, is a trivial aspect of union security. Clearly in the skilled trades and in the maritime trades, control over hiring is a means for apportioning what American labor has generally regarded as scarce opportunities-jobs-and of protecting them for a favored group. The closed shop is, in many ways, a symptom of this scarcity consciousness, and the attacks upon its prohibition must be regarded in that light. But in the mass-production industries, control over hiring has not been an important objective of unions, since such control would impose upon the union the great administrative burden of furnishing labor to the employer. Where the number of workers involved is relatively small, the advantages to be gained from job control outweigh the costs involved in administering an employment office. But where the number of employees required by a single employer may run into tens of thousands, and where considerable changes in the number of employees take place regularly, the cost to the union would probably be greater than could be justified in terms of the advantage gained. Under the pre-Taft-Hartley union shop, the security of the union against internal disruption and external aggression by rival unions and by hostile employers was maximized. Unions could and did discipline their members on the ground of attempting to disrupt the union, or of dual unionism. Some unions made ineligible for membership certain classes of individuals, such as communists, or, as in the case of the NMU, convicted narcotics and sex offenders. What is more significant, the union was able to secure the discharge or suspension of employees on disciplinary grounds.

Under the limitations imposed by the Act, effective parity between the illegal closed shop and the legal union shop no longer exists. Internal discipline can be maintained only at the potential cost of losing members. While the argument that the employer can force all sorts of "undesirables" into the union is clearly invalid, it is equally clear that the union has the alternative of either losing some of its actual or potential members, or admitting anyone who wants to join. In this sense, there is merit in the argument that the union security permitted under the law is of small value. On the other hand, to the extent that the union's bargaining strength is derived from financial strength, the argument is without merit, since clearly the union shop, in whatever form, maximizes the union's dues income (unless the demand for the labor represented by the union is inelastic, and the union takes account of this fact in the level of its dues). 
Section $14(b),{ }^{20}$ which, in effect, delegates to the states the authority to permit or prohibit the union shop within their respective boundaries, comes under frequent attack. Most of the articles in this category attack the procedure on the ground that it represents an improper cession of federal power to the states. Thus, when the NLRB General Counsel refused to conduct authorization elections in "right-to-work" states, on the grounds that union-shop contracts could not be negotiated in any event, the Typographical Journal accused him of taking it upon himself to enforce state laws. ${ }^{21}$ This particular argument is clearly without merit. The great flood of applications for such elections for a time threatened complete breakdown of the operations of the Board, and its decision would seem reasonable in view of the fact that the outcome would be of no effect in any case. One may argue, on the other hand, that an overwhelming affirmative vote, such as frequently resulted in such elections, would give advocates of the union shop fairly good ammunition in their fight for repeal of state "right-to-work" laws. While the argument was never found in this form, it may be that it was in the minds of some of the union editors. It must also be recognized, however, that had the Board consented to hold elections under the circumstances in question, it would implicitly have taken sides in a major controversy and it would unquestionably have undermined its own integrity in so doing.

An argument with a good deal of merit is found in a number of cases to the effect that section $\mathrm{I}_{4}(\mathrm{~b})$ is sharply discriminatory against unions, in the sense that state law is made to apply only where it is more restrictive than federal law, but where the reverse is true, the latter applies. ${ }^{22}$ Certainly it is rare to make substantive rights granted under federal law, in an area occupied by federal law, subject to limitation or veto by state legislation. The fact that this is done here lends considerable color to the discrimination charge, particularly in view of the rather ironic circumstance that section I4(a) explicitly denies any protection of the Act to supervisory personnel, whether or not there exists any conflicting provision of state law. ${ }^{23}$

Numerous articles charge that section $\mathrm{I}_{4}$ (b) has had the effect, if not the intent, of encouraging states to enact "right-to-work" laws.

\footnotetext{
${ }^{80} 61$ Stat. 151 (1947), 29 U.S.C. $\$ 164$ (b) (1958).

${ }^{31}$ NLRB to Enforce State Anti-Union Laws, I 12 Typographical J. $45^{8}$ (1948).

${ }^{22}$ E.g., Double Standards, Catering Industry Employee, March 1953, p. 2.

${ }^{23}$ 6r Stat. 15 I (1947), 29 U.S.C. \& 164 (a) (1958).

24 125 Trpographical J. 277 (1954); U.M.W.J., March x, 1954, p. 33 CIO News, Sept. 29, 1952, p. 7; 114 TYPOGRAPHICAI J. 145 (1949).
} 
The available evidence with respect to most such laws does not sustain the charge. Examination of table I reveals that twelve laws were passed in 1947 or earlier. While it is true that only the Florida law was in existence before 1947, it is difficult to believe that the eleven state legislatures that passed such laws in 1947 were actuated by foreknowledge of what the Taft-Hartley Act was to contain. A more plausible explanation seems to be that section $\mathrm{I}_{4}(\mathrm{~b})$ was included in the act as a result of pressure from some of the states, and that the enactment of the state laws was provoked by the growth of unions all over

TABLE I

STATES WITH RIGHT-TO-WORK LAWS IN 196I, AND YEAR OF ENACTMENT

\begin{tabular}{|c|c|c|c|}
\hline State & Year of Enactment & State & Year of Enactment \\
\hline 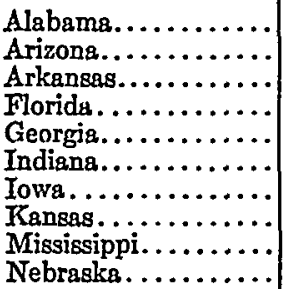 & $\begin{array}{l}1953 \\
1946,1947 \\
1947 \\
1944 \\
1947 \\
1957 \\
1947 \\
1955,1958 \\
1954 \\
1947\end{array}$ & 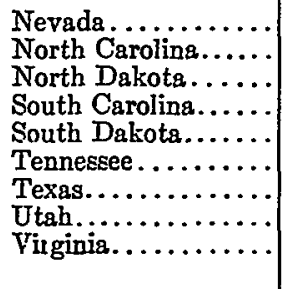 & $\begin{array}{l}1951,1952 \\
1947 \\
1948 \\
1954 \\
1917 \\
1947 \\
1947,1951 \\
1955,1954 \\
1947,1954\end{array}$ \\
\hline
\end{tabular}

BouRcts: 35 LRRM 3022 (1954), 36 LRRM 3050 (1955), 42 LRRM 2127 (1958), 43 LRRM 73 (1959).

the country as a result of World War II and of generally favorable economic conditions. The fact is that the first congressional mention of the subject matter of section I4(b) is found in the Hartley Bill, introduced on April IO, 1947, after nine of the eleven state laws enacted in 1947 had already been approved. ${ }^{25}$ Probably the main point here- is that unions quite honestly feel that this provision is discriminatory, but are themselves not too discriminating in their choice of arguments.

\section{III}

\section{UnIon-Shop Prerequisites}

The prerequisites for the negotiation of union-shop agreements have been presented above: the union must be the majority representative of the employees in an appropriate bargaining unit; it must be in compliance with the filing requirements of the Act; and, until I95I, an authorization election was required.

\footnotetext{
${ }^{25}$ NLRB, Legislative History of the Labor Management Relations Act, 194757 (1948).
} 
The first of these conditions, representative status, however acquired, may normally be expected to precede union-shop negotiations in any event. Hence, the argument, found occasionally, that a union-shop election would have to be preceded by a representation election, thus requiring all the more time, ${ }^{26}$ appears to originate in a vacuum, except under very special circumstances. It is interesting to note, however, that when it was proposed to remove the requirement of a representation election explicitly in those cases where employment is normally of a casual nature, the CIO opposed the change, on the ground that it was ". . . a device to aid 'Sweetheart Pacts." ")27 On the other hand, the AFL, and particularly the building-trades unions, strongly endorsed the amendment, which, nonetheless, failed.

Little attention is devoted to the filing requirements as prerequisites to the union shop, though they come in for much comment in other connections. The only comment here comes from the United Electrical Workers Union, which describes the entire union-shop procedure as a fraud designed to "ensnare" unions into compliance with the filing requirements. ${ }^{28}$ It may be pointed out that the UE subsequently thus ensnared itself in its unsuccessful struggle for existence after its expulsion (withdrawal?) from the CIO.

One of the requirements of the authorization election procedure had been that a majority of those eligible to vote must vote affirmatively. This requirement is widely attacked on the ground that it is discriminatory, since this type of supermajority is required in virtually no other election, and in none under the Taft-Hartley Act. Clearly this argument is valid. Such voting requirements are generally reserved for approval of bond issues and the like in local elections. The requirements seems to reveal a congressional intent to make it as difficult as possible for unions to negotiate a union shop. A special burden is placed on those employees who favor the union shop, since those who oppose it need do nothing, failure to vote amounting in effect to a "no" vote.

This requirement also comes in for a certain amount of ridicule. Thus, it is argued that Congress ought to put the same requirement on its own election, in which case most members could not hold their seats. It is also argued, evidently on the basis of experience, that employees who quit or die in the interval between the establishment of the eligi-

\footnotetext{
${ }^{28}$ The Taft-Hartley Act, Ammunition, Aug. r947, p. 6.

${ }^{27}$ CIO News, Sept. 10, 195I, p. 2.

${ }^{28}$ Across the Board, UE News, Oct. 25, 1947, p. I1.
} 
bility list and the election remain on the list and thus effectively vote against authorization. ${ }^{29}$

The requirement for an authorization election must be regarded as an expression of the belief on the part of Congress that workers feel a need of protection against the power conferred upon the union by the union shop. This notion comes in for considerable criticism, particularly by the American Photo-Engraver, ${ }^{30}$ and appears well-founded in the light of the results of the authorization polls. As indicated in table II, 97 per cent of all elections resulted in authorization, with 90 per cent of those voting, and 78 per cent of those eligible, voting for authorization. If there were a strong undercurrent of feeling against the union shop, one might expect either a strong protest vote or wholesale abstention. It is obvious that neither took place. The results shown in the table are strong evidence denying the validity of the congressional premise, even if one is inclined to agree with the argument that they indicate a

TABLE II

UNION SHOP ELECTIONS AND RESULTS, I947-5I

\begin{tabular}{|c|c|c|c|c|c|}
\hline Election Results & $1948^{\mathrm{B}}$ & 1949 & 1950 & $1951^{b}$ & $1947-51^{\circ}$ \\
\hline 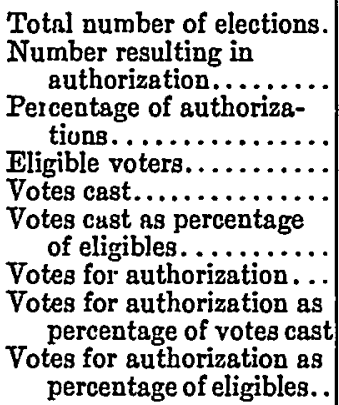 & $\begin{array}{r}17,958 \\
17,601 \\
97.9 \\
1,852,333 \\
1,629,330 \\
87.9 \\
1,534,980 \\
94.2\end{array}$ & $\begin{array}{r}15,074 \\
14,581 \\
96.7 \\
1,733,922 \\
1,471,092 \\
844.9 \\
1,381,829 \\
94.9\end{array}$ & $\begin{array}{r}5,589 \\
5,376 \\
96.2 \\
1,072,856 \\
900,807 \\
84.2 \\
805,160 \\
89.4\end{array}$ & $\begin{array}{r}7,525 \\
7,265 \\
96.6 \\
1,885,890 \\
1,547,753 \\
81.9 \\
1,351,273 \\
87.3\end{array}$ & $\begin{array}{r}46,146 \\
44,823 \\
97.1 \\
6,545,001 \\
5,548,982 \\
84.8 \\
5,073,242 \\
90.1\end{array}$ \\
\hline
\end{tabular}

Norss: a Fiseal years.

July 1, 1950-Oct. 22, 1951.

Eougce: Adapted from 17 NLBB $\triangle$ NN. BEP. 306 (1952).

desire to demonstrate group solidarity, as much as a desire to operate under the union shop. ${ }^{31}$

Another argument against the elections is that they have tended to pre-empt the attention of the Board, at the expense of other and more

\footnotetext{
${ }^{20}$ Under T-H: Absence Makes "Noes" Grow Unfonder of Union Shop, CIO News, July 26, 1948, p. 8.

${ }^{30}$ Another Noble Experiment Dies, 43 AMERICAN Photo-ENGRaver I202 (I95I); Wrong Bill of Goods, 42 AMERICAN Photo-ENGRAVER II3 (1950).

${ }^{31}$ WolletT, Labor Relations and Feberal LAW 70 (I 949 ).
} 
important matters, specifically employer unfair labor practices, ${ }^{32}$ and that in any event, the procedure is a waste of time and money for unions and for taxpayers alike, since the results in virtually all cases are perfectly predictable. ${ }^{33}$ The latter of these contentions seems to be borne out by the evidence cited above. Further, there is slender evidence to substantiate the contention, made elsewhere, ${ }^{34}$ that the continuation of the election procedure would have tended to moderate the "right-towork" movement in the last several years; while it is true that no further state laws of this nature were passed between 1947 and 195 I, only two states passed such laws between $195 \mathrm{I}$ and $19533^{35}$ while four were passed in 1954, of which one has since been repealed. ${ }^{30}$ In 1958, the movement received a rather solid set-back when the voters of only one state accepted, while those of five states rejected such laws. ${ }^{37}$

The former of the two arguments-i.e., that the elections consumed an unconscionable amount of the Board's time, appears to be borne out by the Board's own reports. In fiscal 1948, the Board received over 35,000 cases, of which more than 26,000 were petitions for authorization elections. This compares to a total case load of 15,000 in fiscal 1947. As a result, in 1948, only about half as many representation elections were conducted as in 1947. Also, in 1947, the Board closed a total of 4,014 unfair labor practice cases, while only 3,643 such cases were closed in $1948 .^{38}$

While most segments of labor supported the repeal of the election requirement as a step in the right direction, the change was not regarded as a great improvement. The move for repeal had been introduced as early as 1948 in the Ives-Landis bill, which was, however, defeated. At that time, the CIO opposed repeal on the ground that it was merely intended to protect employers from the embarrassment caused them by the election results. ${ }^{39}$ These results were used as a club in many negotiations, with the suggestion that they imposed a moral duty on employers

\footnotetext{
${ }^{32}$ Pilot, Nov. 30, 3950, p. 5 .

${ }^{83}$ CIO News, Dec. 12, 1949, p. 2.

sc Cohn, Union Shop Polls: A Solution to the Right-to-Work Isste, 12 INDUSTRIAL AND LABOR RELATIONS REVIEW 252 (1959).

${ }^{35}$ Alabama and Nevada. See Table I.

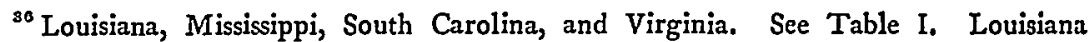
repealed its law in 1956.38 L.R.R.M. 3 (1956).

${ }^{37}$ Right-to-work proposals were defented in California, Colorado, Idaho, Ohio, and Washington. Kansas passed a right-to-work law. 43 L.R.R.M. 73 (1959).

${ }^{38}$ I 3 NLRB ANN. ReP. 11, 96-97 (1948); 12 NLRB ANN. ReP. 2, 84 (1947).

${ }^{80}$ CIO News, May 10, 1948, p. 2.
} 
to agree to a union shop. The UMW, however, was the only union among those examined, to go on record in opposition to repeal. It accused the leaders of the federations of duplicity, in that they had retreated from their earlier insistence on repeal of the entire Act, ${ }^{40}$ and argued that the only result of the amendment would be to get Senator Taft, one of the sponsors of the amendment, ". . . off the political hook." 31

\section{IV}

The Maritime Hiring Hall

It was indicated at the begining of this article that the relation of the Taft-Hartley Act to the hiring hall is, in fact, a special case of the more general problem of the closed shop. In the specific case studied, however, that of the reaction of the NMU, certain special conditions supervened to create a particularly violent reaction. In the first place, the Port of New York, the NMU's major area of operation, was, until very recently a classic case study in the contrast between maritime operations with and without a hiring hall, with particular emphasis on the deplorable conditions persisting in longshoring. But this aspect of the problem is implicit in the arguments, rather than explicit, with various references to the evils of the shape-up, the crimp joint, and so forth. The second of the conditions alluded to above was that at the expiration of the NMU contracts providing for the hiring hall, on June I5, 1948, the union was in the throes of a severe internecine struggle for control between a Communist faction on the one hand, and Joseph Curran, the president, and his more or less anti-Communist faction on the other. With this vicious struggle about to come to a head in the union's election of officers, neither faction could afford to concede the possibility of a compromise on the hiring hall. Nonetheless, when a national emergency injunction was issued in the face of a threatened strike over the hiring hall, the Communist faction accused Curran of preparing for a compromise when he refused to call a strike and insisted that a strike in violation of the injunction would seriously imperil the future existence of the union. Curran, in his turn, accused the Communists of wanting to precipitate a strike in violation of the injunction since they were about to suffer defeat in the election. ${ }^{42}$ Cur-

"Some More Shenanigans on Hill as Congress Enacts Taft Amendment, U.M.W.J., Oct. I5, I95x, p. I5.

"Another Weird T-H Development, U.M.W.J., Aug. 15, 1951, P. 5.

${ }^{2}$ Curran, Passing the Word, Pilot, July 2, 1948, p. 2. For the Communist view, see Council Drafts Plan to Meet Fight. . . , Pilot, July 2, 1948, p. 5. 
ran's argument was, in essence, that the Communist faction was willing to gamble the life of the union against their control of it.

What followed thereafter might well be entitled "The Natural History of a Compromise." The union, after the defeat of the Communist faction, entered into an agreement with the ship operators under which the hiring hall was continued without modification, pending litigation before the NLRB and the courts. When the Board's decision against the hiring hall was made public in April, I949, the union was once again involved in negotiations, and promptly accused the Board of trying to wreck these negotiations. The union then stated its policy on the matter in apparently unequivocal terms, as follows: "Any agency that believes it can destroy the hiring hall, must be ready to destroy and wipe out the union, because maritime workers will fight such attempts to the bitter end." 43

The agreement that was finally negotiated once again included the hiring hall, pending final determination of the issue by the courts, and in the hope that some legislation, either general or special, would be forthcoming to legalize the existing arrangement. To meet all eventualities, however, a termination clause was included that was to become operative should the hiring hall as constituted be found illegal in a final proceeding. When it became obvious that no legislative relief was forthcoming and that all efforts to retain the hiring hall in its existing form were destined to fail, the way was gradually paved for compromise. In November 1949, an article appeared that stated that the union can not "strike against the courts"4-i.e., in violation of a final order. The same article also described, for the first time without acidulous comment, the Pacific Coast Maritime Agreement of the Sailors Union of the Pacific. The latter agreement, rumored to have been worked out between the late Senator Taft and Harry Lundeberg, sidestepped the preferential hiring issue. An agreement on this model was finally reached on the East Coast in I950 embodying the following wording:45

In the hiring of Unlicensed Personnel the Company will prefer competent and dependable applicants who have been previously employed on vessels of one or more of the Companies under agreement with the Union, and the Union, in furnishing Unlicensed Personnel to the Company through the

${ }^{43}$ Danger Ahead, Pilot, April 22, 1949, p. 2. (Emphasis added.)

"Taft-Hartley Law and the Hiring Hall, Pilot, Nov. 17, I949, p. 19.

${ }^{45}$ NMU Preserves Hiring Hall, Pilot, June 15, 1950, p. x. (Emphasis added.) 
facilities of its employment offices will recognize such preference and refer Unlicensed Personnel to the Company with due regard thereto.

The union agrees to maintain, administer, and operate its employment offices in accordance with law and assumes sole responsibility therefor.

Obviously, to the extent that the italicized portions of the quoted clause were adhered to, this represented no fundamental change in the modus operandi of the hiring hall, since those to whom the companies "give preference" must necessarily have been members of the union. ${ }^{46}$ For the next several years, the issue was dormant, largely because of the sizeable volume of shipping and the consequent demand for seamen originated from the Korean War, but it was revived in I954 as a result of a Board decision relating to the permit card system, which forced the union to admit new members. ${ }^{47}$

While the fundamental issue at stake in the debate over the hiring hall is the same as in the case of the closed shop-namely, control over hiring, virtually all of the articles found among the periodicals covered in this survey originate in the NMU's Pilot, for obvious reasons. A few words may be in order to place this issue in its proper perspective in the maritime trades, as distinct, perhaps, from the closed-shop issue in other industrial areas. Employment in the maritime trades is generally on a casual basis for unlicensed personnel, as well as for some of the licensed personnel. A merchant seaman normally signs up for a single voyage or for several successive voyages, depending on their length, after which he commonly takes some time off for rest, family life, recreation, perhaps a shoreside job, and so forth. The ship operator is consequently always in need of workers, since the latter move from ship to ship, from company to company, to take what jobs are available when they want them. Under the union hiring hall, the operator obtains workers from the hiring hall only. The dispatcher, an elected official of the union in the hiring hall, dispatches men with the appropriate qualifications who are currently available for work. Dispatching is presumably done in order of rotation on the so-called shipping list, a roster of all members shipping out of the particular port, broken down according to rating. If an individual is not available when called or is unwilling

${ }^{6}$ The Supreme Court recently held that a hiring-hall agreement that expressly prohibited union preference was not illegal per se under the Taft-Hartley Act. Local 357 , International Bhd. of Teamsters v. NLRB, 365 U.S. $66_{7}$ (1961). The Court, pointing out the economically useful features of the hiring hall, specifically rejected the Board's ruling in Mountain Pacific, I is NLRB 883 (1958).

${ }^{4}$ Permanente S.S. Corp., 107 NLRB IIII (1954). 
to take a particular job, his name is returned to the bottom of the list. The operator has the option of rejecting a man he does not want on specified grounds, such as drunkenness, incompetence, fighting on board, and so forth, but a rejected man retains his place at the top of the shipping list until hired.

Since the hiring hall is operated by the union at its own expense, une would expect that only union members will be dispatched; and under the hiring contracts in existence when the Taft-Hartley Act came into force, the operators could hire only through the union. If the union could not furnish enough men, as happened on occasion, a permit-card system was used, under which nonunion applicants could be dispatched on payment of a fee. Admission of new members were rare, because the union feared that the normal volume of employment would decrease with the end of the war and decrease the average amount of employment to all members if membership was expanded.

Before the union had won the hiring hall, recruitment was commonly done on the dock and from various other places, such as waterfront taverns, flophouses, and the so-called crimp-joint. These methods of hiring, especially when jobs were scarce, led to favoritism, kick-backs to the hiring boss, and similar abuses, popularized in recent years in connection with some of the investigations of the New York Waterfront Commission. The union hiring hall, at least in theory and very likely in fact, abolished all of these abuses after vicious struggles on both coasts in the I930's.

The emotional fervor generated within the NMU by the ban on the hiring hall may be appreciated by considering that half of all of the Pilot articles on the various phases of the Taft-Hartley Act dealt with this issue alone. While, as suggested above, this struggle in its early stages was closely related to the factional strife within the union, the tone of the articles suggests that it did not merely reflect agitation on the part of the leaders of the union concerned with maintaining the power the hiring unquestionably conferred upon them, but reflected fairly accurately the feelings of the membership at large, who related the improvements in their working conditions very definitely to the establishment of the hiring hall.

\section{V}

\section{ConcLusron}

The agitation on the part of unions following the passage of the Taft-Hartley Act fourteen years ago, especially with respect to the 
union-security. provisions of the Act has in more recent years abated. It is impossible, of course, to discern whether or to what extent the decline of the concern evinced earlier is due merely to the passage of time, to resignation with respect to the possibility of alteration, or to the fact that labor has found it possible to operate within the existing framework of law. It would appear that the labor movement continues vigorous and that it has turned much of its political effort in other directions, particularly toward action at the state level.

Whether labor could by more astute strategy have obtained desired changes in the Act is, of course, problematical; that its strategy was poor appears obvious. Whatever truth may be found among the sensational revelations of the McClellan Committee, the McClellan hearings themselves are certain to have damaged sharply the prospects of any state or federal legislation favorable to unions, particularly with respect to union security. (One may, indeed, wonder whether an effect of this sort was not intended at the inception of the hearings). Had the AFL-CIO shown the same courage with respect to racketeering and sloppy financial practices in some of its member unions as did the CIO in 1949 with respect to Communist-dominated unions, recent restrictive legislation at the federal level might have been averted, and the "right-to-work" movement might have been weakened even more than was indicated by the 1958 elections. As the matter stands, the "right-to-work" movement has probably gained considerable strength from the hearings.

While radical changes in the status of union security appear unlikely, one may speculate as to the attitude unions are likely to display in this respect in the near future. Assuming that unions and employers will be guided by the concept of peaceful co-existence, it is likely that the issue of union security under federal law, with the possible exception of section $I_{4}(b)$, will be dormant. Where unions enjoy the loyalty of most of the employees in a bargaining unit, the security afforded the union by the union-security provisions of the Taft-Hartley Act would appear to be ample under most circumstances. On the other hand, should employers in considerable numbers make a determined effort, with the aid of the McClellan Committee records and astute public-relations advice, to undermine unions with which they have contractual relations, one may expect unions to bring the union-security issue very much to the fore again. It remains to be seen whether the recent phase of exacerbated industrial conflict is symptomatic of a long-run deterioration 
of relations between employers and unions, or whether it was merely a passing phase attributable to the aftermath of the 1958 recession. If the former, the result posited above may be expected to materialize. If the latter is true, as is to be hoped, one may suspect that with the appearance of a new generation of unionists (and of employers), liberated from the folklore of early-twentieth-century unionism, a new phase in union-management relations may appear in which union security as a fighting issue between the parties will be regarded as an anachronism of the antedeluvian period, perhaps to be worshipped in public but not to be taken seriously in private. 